\title{
KEPROSPEKAN PANAS BUMI GUNUNG UNGARAN BERDASARKAN ANALISIS GEOSAIN TERPADU
}

\author{
Oleh: \\ Ahmad Zarkasyi, Yuanno Rezky, Mochamad Nurhadi \\ Pusat Sumber Daya Geologi \\ Jl. Soekarno Hatta No. 444, Bandung.
}

\section{SARI}

Survei geosain dan pemboran empat sumur landaian suhu di daerah Gunung Ungaran dilakukan secara terpisah dan dikerjakan oleh konsultan yang berbeda, akibatnya tidak ada laporan hasil survei yang terpadu. Hasil kompilasi pengolahan, analisis dan interpretasi ulang data survei terdahulu menunjukan tiga kelompok daerah panas bumi di sekitar Ungaran yaitu Gedongsongo, Nglimut dan Kendalisodo. Laporan terdahulu memperkirakan potensi Ungaran $100 \mathrm{MWe}$. Hasil review data survei mempelihatkan prospek panas bumi Gunung Ungaran berada di sekitar daerah Gedongsongo dan Nglimut dengan total luas prospek $10 \mathrm{~km}^{2}$ dan perkiraan potensi terduga $110 \mathrm{MWe}$.

\section{Kata Kunci: Panas bumi, Gunung Ungaran, Geosain, Gedongsongo}

\section{ABSTRACT}

Geoscientific survey and drilling four gradient temperature bor holes in Ungaran Mountain had been carried out independently and excuted by different consoultants. Consequently, there is no integrated report. Compilation of re-processing, re-analysis, and re-interpretation of survey data reveal three groups geothermal area in Ungaran: Gedongsongo, Nglimut and Kendalisodo. The previous surveys estimated energy potential of Ungaran of $100 \mathrm{MWe}$. The result of survey data review shows that Ungaran Mountain geothermal prospect is located around Gedongsongo and Nglimut area with prospect coverage of $10 \mathrm{~km}^{2}$ and has possible energy potential of approximately $110 \mathrm{MWe}$.

\section{Key words: Ungaran Mountain, Geothermal, Geo science, Gedongsongo}

\section{PENDAHULUAN}

Gunung ungaran merupakan salah satu area bersistem panas bumi yang ditandai dengan mata air panas, fumarol, tanah panas, endapan travertin dan batuan teralterasi. Secara administratif Gunung Ungaran termasuk dalam Kabupaten Semarang, Jawa Tengah. Lokasi manifestasi panas bumi terutama terletak di lereng barat-laut, baratdaya dan tenggara Gunung Ungaran

Untuk memanfaakan potensi panas bumi suatu area dibutuhkan suatu proses penelitian yang bertujuan mengindetifikasi sistem panas buminya. Pertamina pada periode 1983 sampai dengan 1988 telah melakukan survei pendahuluan geosain dengan metode geologi, geokimia, geofisika dan pengeboran landaian suhu untuk mengetahui keprospekan panas bumi di daerah Gunung Ungaran.

Semua kegiatan survei di atas dilakukan secara terpisah dan dikerjakan oleh konsultan yang berbeda sehingga tidak ada laporan hasil kegiatan yang terpadu. Sebagian besar laporan hasil survei tersedia dalam bentuk fotokopi, gambar, peta dan grafik masih dalam format analog. Penulis mencoba mengintegrasikan dan menginterpretasikan kembali data yang ada yang meliputi data geologi, geokimia dan geofisika (gaya berat, geolistrik dan magnetotellurik) untuk mendeskripsikan sistem panas bumi daerah ini.

Metode yang dilakukan penulis adalah menganalisis data mentah yang terdapat pada laporan terdahulu, memproses ulang data dan meinterpretasi hasil dari proses ulang tersebut. Maksud dan tujuan dari me-review data tersebut adalah meindetifikasi karateristik sistem panas bumi dan mendeliniasi luas prospek serta menghitung perkiraan potensi energinya.

Karateristik sistem panas bumi meliputi sumber panas, lapisan resevoir, lapisan penudung dan fluida panas. Untuk mengindetifikasi sistem panas bumi maka diperlukan informasi kegeologian dan analisis manifestasi panas bumi yang ada di daerah tersebut. Untuk mendeliniasi daerah prospek maka dilakukan analisis anomali-anomali dari berbagai metode yang kemudian dikompilasi 
secara terpadu. Sedangkan untuk penghitungan potensi panas bumi, digunakan data hasil geotermometer manifestasi yang dikombinasikan dengan hasil identifikasi sistem dan deliniasi area prospek panas bumi.

\section{TINJAUAN PUSTAKA}

Gunung ungaran merupakan salah satu area bersistem panas bumi yang ditandai dengan mata air panas, fumarol, tanah panas, endapan travertin dan batuan teralterasi. Secara administratif Gunung Ungaran termasuk dalam Kabupaten Semarang, Jawa Tengah. Lokasi manifestasi panas bumi terutama terletak di lereng baratlaut, baratdaya dan tenggara Gunung Ungaran

Untuk memanfaakan potensi panas bumi suatu area dibutuhkan suatu proses penelitian yang bertujuan mengindetifikasi sistem panas buminya. Pertamina pada periode 1983 sampai dengan 1988 telah melakukan survei pendahuluan geosain dengan metode geologi, geokimia, geofisika dan pengeboran landaian suhu untuk mengetahui keprospekan panas bumi di daerah Gunung Ungaran.

Semua kegiatan survei di atas dilakukan secara terpisah dan dikerjakan oleh konsultan yang berbeda sehingga tidak ada laporan hasil kegiatan yang terpadu. Sebagian besar laporan hasil survei tersedia dalam bentuk fotokopi, gambar, peta dan grafik masih dalam format analog. Penulis mencoba mengintegrasikan dan menginterpretasikan kembali data yang ada yang meliputi data geologi, geokimia dan geofisika (gaya berat, geolistrik dan magnetotellurik) untuk mendeskripsikan sistem panas bumi daerah ini.

Metode yang dilakukan penulis adalah menganalisis data mentah yang terdapat pada laporan terdahulu, memproses ulang data dan meinterpretasi hasil dari proses ulang tersebut. Maksud dan tujuan dari me-review data tersebut adalah meindetifikasi karateristik sistem panas bumi dan mendeliniasi luas prospek serta menghitung perkiraan potensi energinya.

Karateristik sistem panas bumi meliputi sumber panas, lapisan resevoir, lapisan penudung dan fluida panas. Untuk mengindetifikasi sistem panas bumi maka diperlukan informasi kegeologian dan analisis manifestasi panas bumi yang ada di daerah tersebut. Untuk mendeliniasi daerah prospek maka dilakukan analisis anomali-anomali dari berbagai metode yang kemudian dikompilasi secara terpadu. Sedangkan untuk penghitungan potensi panas bumi, digunakan data hasil geotermometer manifestasi yang dikombinasikan dengan hasil identifikasi sistem dan deliniasi area prospek panas bumi.

\section{Geologi}

Geologi permukaan Gunung Ungaran didominasi oleh batuan vulkanik berumur Kuarter (Gambar 1). Sistem panas bumi yang berkembang di Gunung Ungaran berada di zona depresi. Di zona depresi tersebut muncul kerucut-kerucut muda seperti Gunung Gugon dan Gunung Mergi. Struktur ini merupakan collapse structure yang di sebelah selatan dan barat Gunung Ungaran, berbentuk melingkar dan saling memotong. Struktur tersebut berkaitan dengan kegiatan vulkanisme dari Gunung Ungaran yang terbentuk di atas batuan sedimen laut berumur Tersier. Hasil analisis citra dapat menampilkan (Gambar 1) struktur sekunder yang berkaitan erat dengan sistem panas bumi Ungaran.

\section{Geokimia}

Jenis manifestasi panas bumi yang muncul dan berasosiasi dengan Gunung Ungaran berupa mata air panas, fumarol, tanah panas, endapan travertin dan batuan teralterasi. Berdasarkan lokasi pemunculan manifestasi, terdapat 3 kelompok manifestasi panas bumi yaitu Komplek manifestasi panas bumi Gedongsongo terdiri dari fumarol, yang memiliki suhu paling tinggi, bertemperatur $86^{\circ} \mathrm{C}$, mata air panas bertemperatur $50^{\circ} \mathrm{C}$, tanah panas dan batuan teralterasi. Kelompok manifestasi Ngilimut dengan manifestasi berupa mata air panas bertemperatur $47^{\circ} \mathrm{C}$ dan Kelompok Kendalisodo dengan manifestasi berupa mata air panas bertemperatur $40^{\circ} \mathrm{C}$.

Hasil kajian data kimia air panas, tanah, isotop dan gas diperkirakan bahwa Gedongsongo merupakan daerah upflow sistem panas bumi Gunung Ungaran. Perkiraan tersebut diperkuat oleh keterdapatan jenis manifestasi fumarole aktif. Data-data lainnya yang menunjang perkiraan ini adalah hasil pemboran landaian suhu USL-1 dimana harga landaian suhu $10,4^{\circ} \mathrm{C} / 100 \mathrm{~m}$ atau lebih kurang 3 kali nilai landaian suhu normal serta terdapatnya mineral temperatur tinggi berupa ilit dan klorit.

Penyelidikan terdahulu menggunakan geotermometer air panas untuk memperkirakan temperatur resevoir. Hasil estimasi temperatur reservoir dengan geotermometer air panas berkisar $\pm 189-236^{\circ} \mathrm{C}$. Hasil ini memiliki rentang temperatur yang cukup lebar. Untuk mendapatkan hasil yang lebih akurat, penulis menggunakan geotermometer gas. Penggunaan ini didasari dari komposisi gas dari fumarol Gedongsongo yang mencirikan adanya pengaruh unsur magmatis dengan temperatur lebih dari $300^{\circ} \mathrm{C}$. Hasil penghitungan dengan geotermometer gas diperoleh temperatur 


\section{MAKALAH ILMIAH}

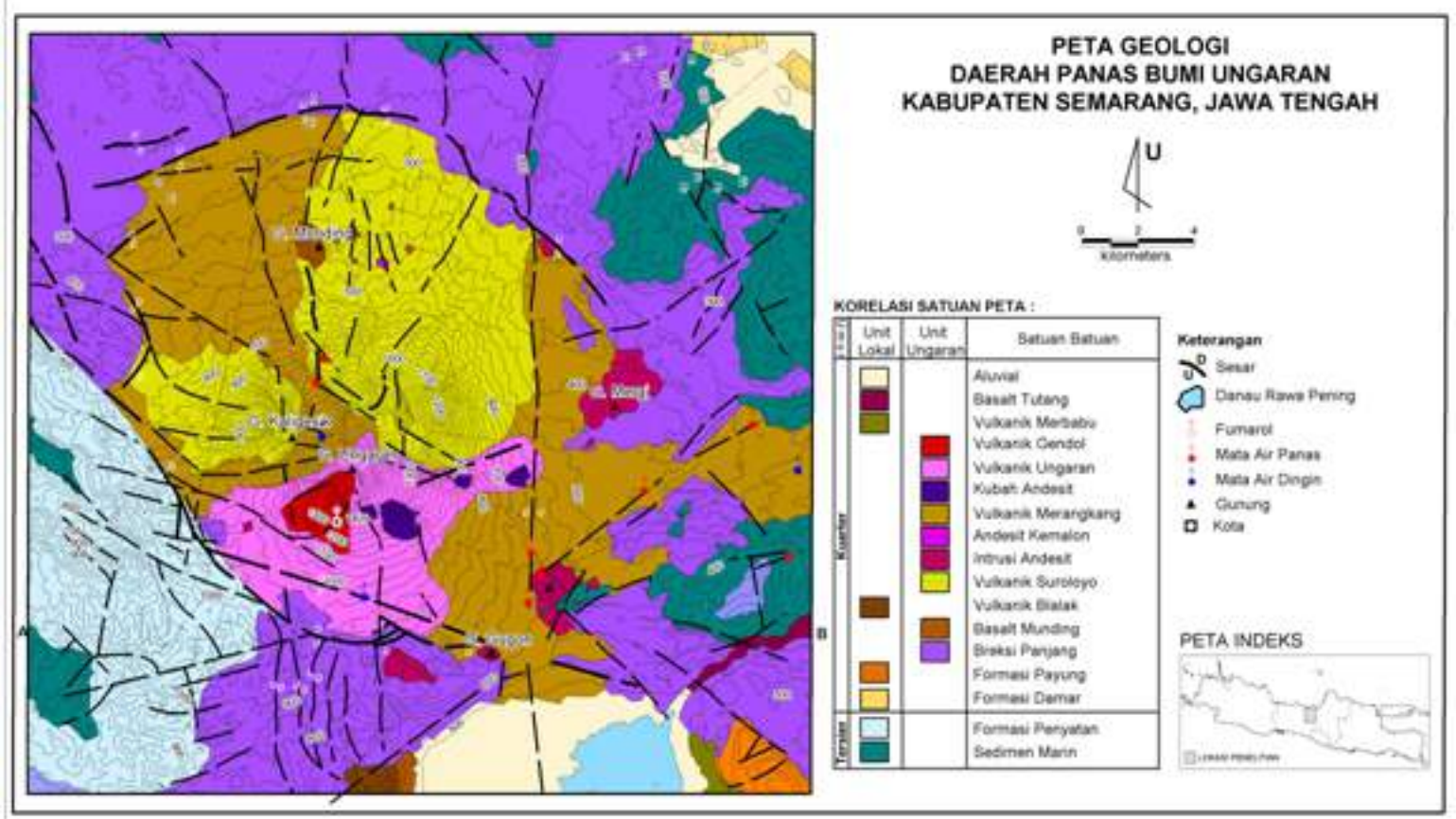

Gambar 1. Peta Geologi daerah Ungaran (modifikasi dari Hadisantono dan Sumpena,1993; Thaden dkk., 1996)

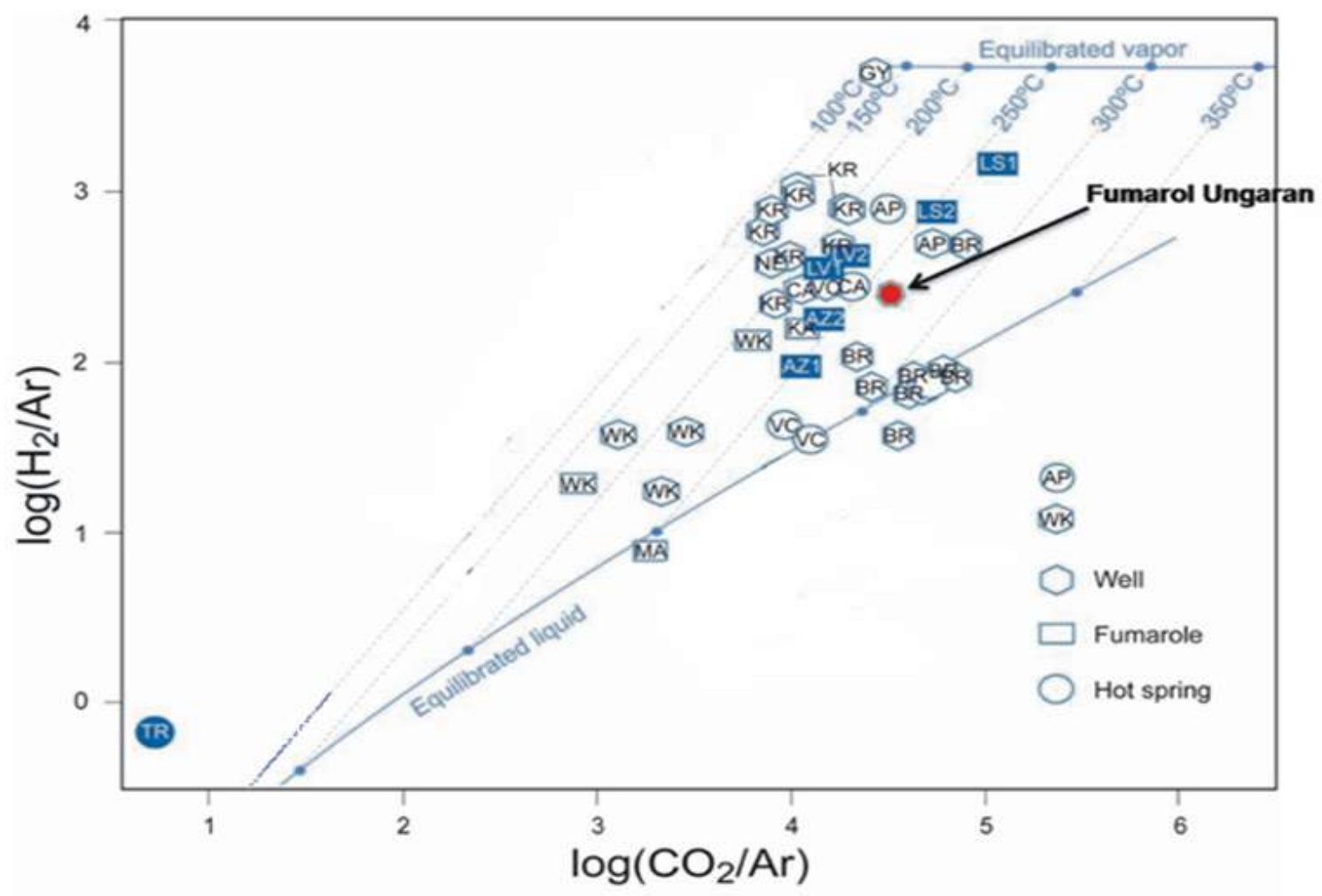

Gambar 2. Plot data Geotermometer gas $\mathrm{CO}_{2} / \mathrm{Ar}-\mathrm{H}_{2} / \mathrm{Ar}$ pada diagram Giggenbach, (1984) 


\section{MAKALAH ILMIAH}

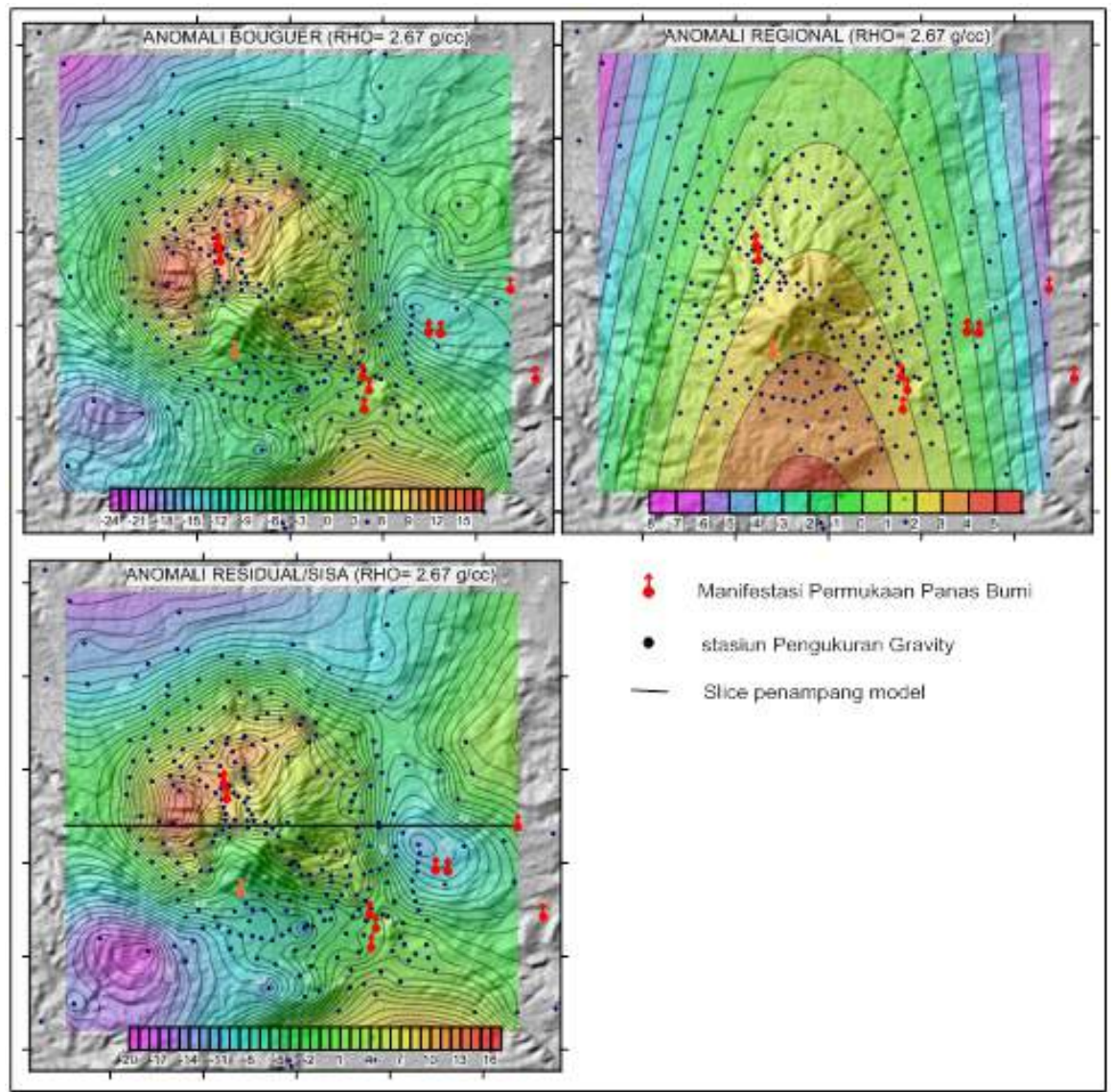

Gambar 3. Peta Anomali Bouguer, Peta Anomali Regional, dan Peta Anomali Residual/Sisa daerah penelitian (Modifikasi dari: Pertamina, 1986)

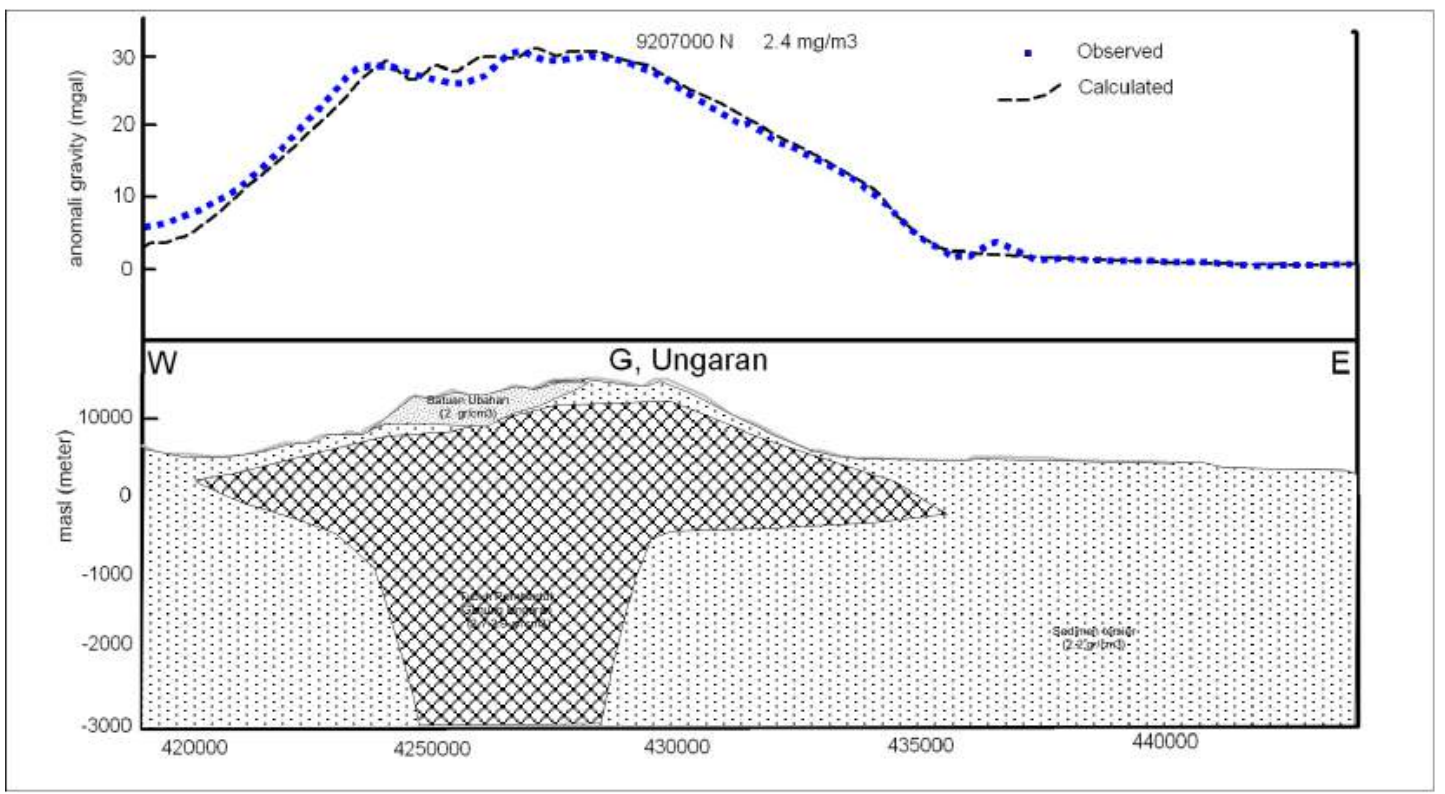

Gambar 4. Penampang model gaya berat 2D Gunung Ungaran (Modifikasi dari: Pertamina, 1986) 


\section{MAKALAH ILMIAH}

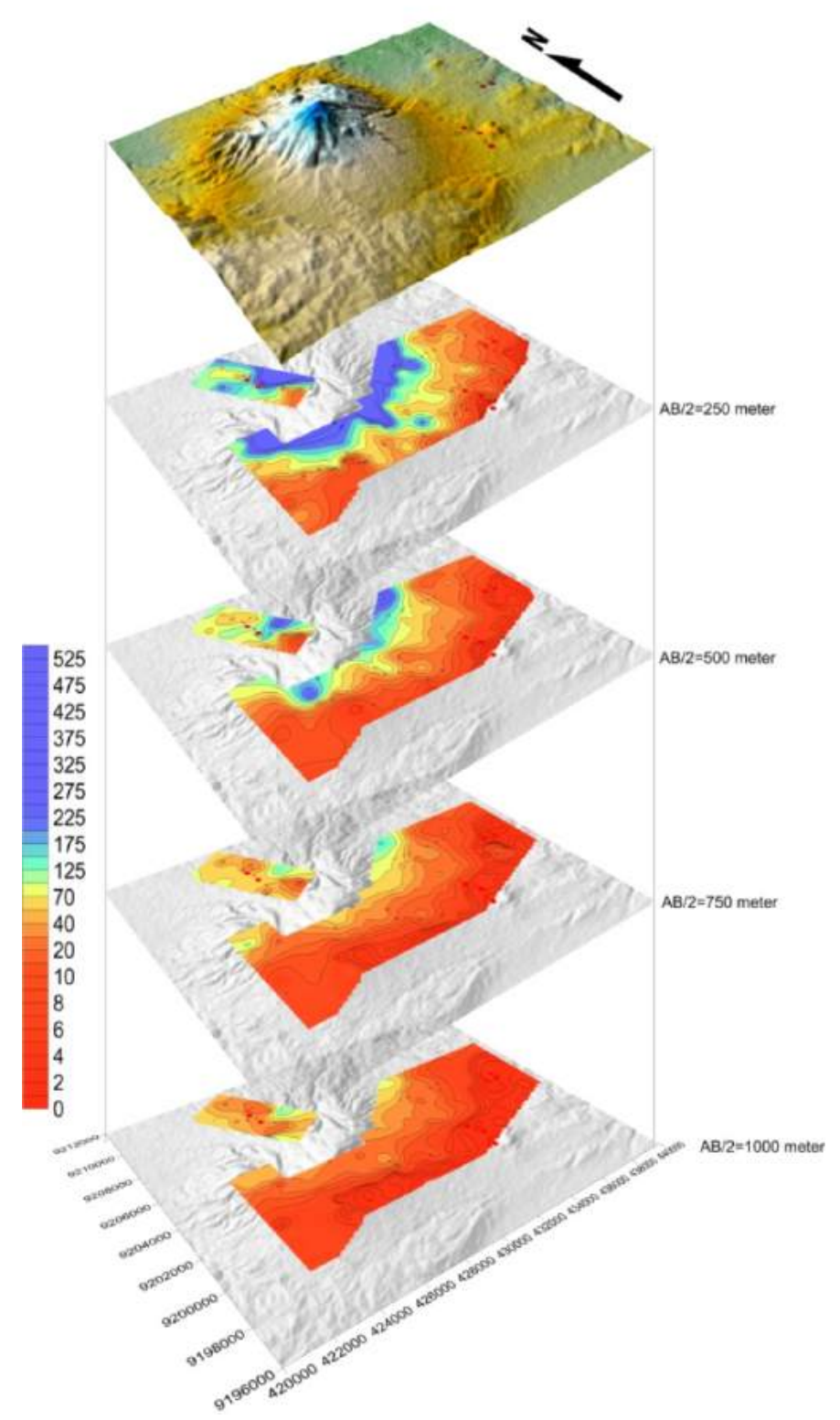

Gambar 5. Peta tahanan jenis semu hasil proses dan interpretasi ulang

reservoir di Gedongsongo sekitar $270^{\circ} \mathrm{C}$ (Gambar 2).

\section{Geofisika}

\section{Gaya Berat}

Peta anomali Bouguer densitas $2,67 \mathrm{gr} / \mathrm{cm}^{3}$ (Gambar 3) memperlihatkan pola kontur berarah baratlauttenggara. Anomali tinggi terkonsentrasi di sekitar Gunung Ungaran yang permukaannya terisi oleh satuan lava andesit .

Anomali gaya berat Bouguer, regional maupun sisa memperlihatkan anomali positif berada di sekitar Gunung Ungaran diinterpretasikan sebagai satuan batuan magmatik dan menempati zona lemah, tempat terjadi aktivitas vulkanisme.

Anomali sisa yang tinggi (>10 mgal) membentuk kontur tertutup yang mencirikan adanya suatu tubuh batuan dengan densitas yang kontras dari sekitarnya di utara Gunung Ungaran. Interpretasi model 2D (Gambar 4) memperlihatkan tubuh dengan densitas 2,72,9 $\mathrm{gr} / \mathrm{cm}^{3}$ terindikasi di bawah Gunung Ungaran 


\section{MAKALAH ILMIAH}

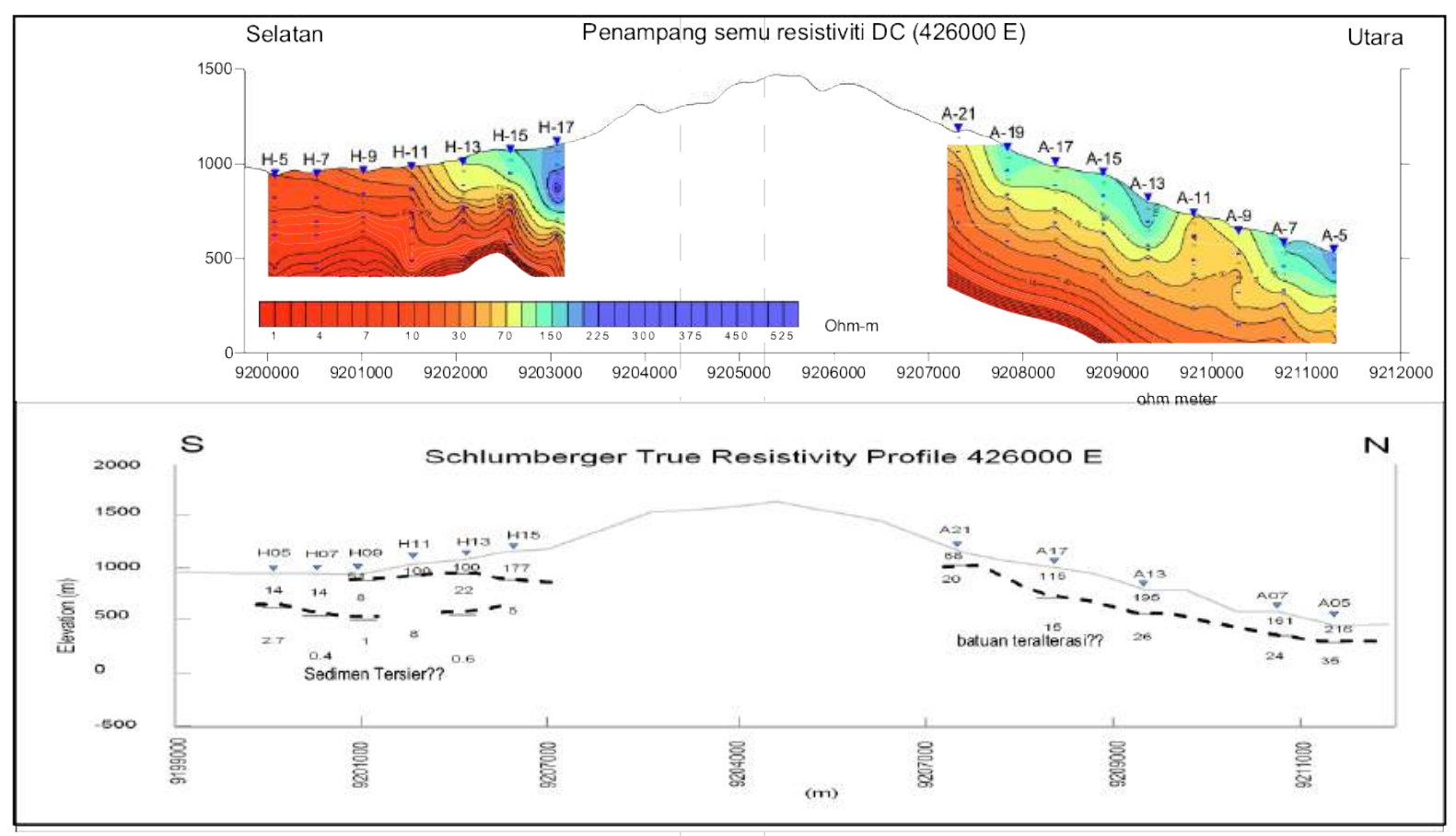

Gambar 6. Penampang tahanan jenis selatan-utara daerah penelitian

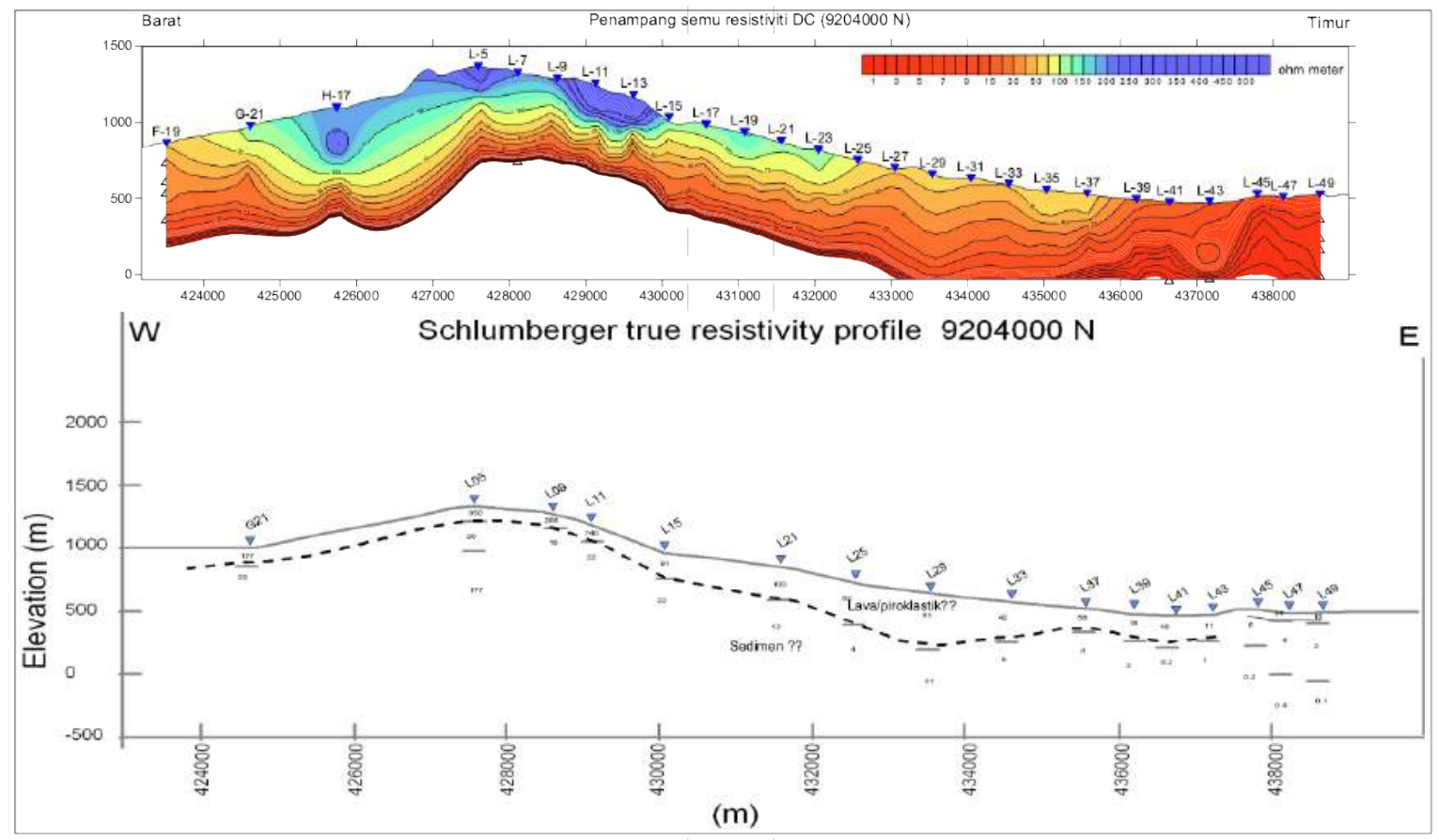

Gambar 7. Penampang tahanan jenis barat-timur daerah penelitian 


\section{MAKALAH ILMIAH}

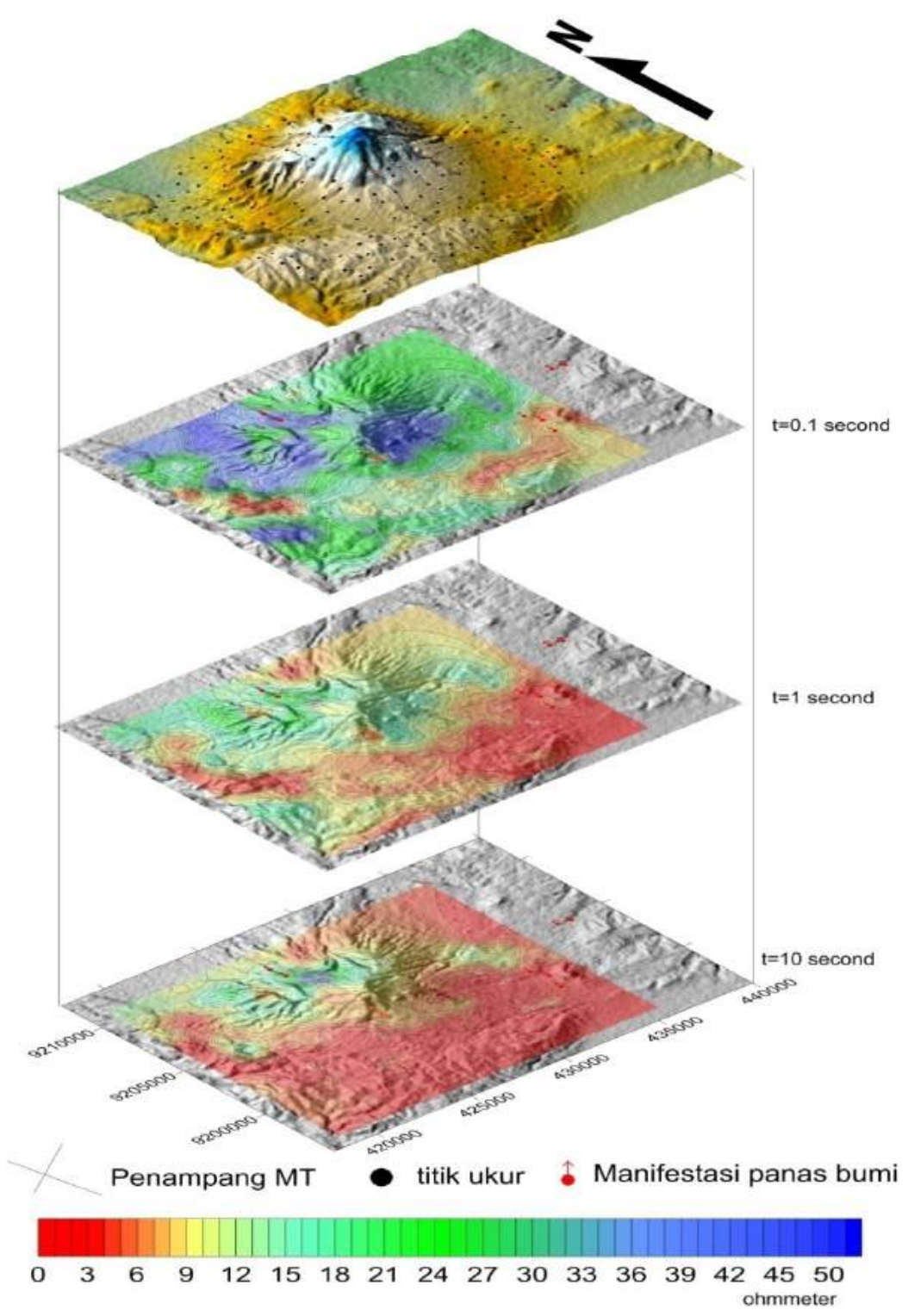

Gambar 8. Peta tahanan jenis semu MT (Pertamina, 1984) dimodifikasi dan re interpretasi

berada pada kedalaman sekitar 250400 diduga merupakan magma yang yang menerobos sedimen Tersier

\section{Geolistrik}

Peta tahanan jenis semu $A B / 2=250,500$, 750 dan 1000 meter (Gambar 5) menggambarkan nilai tahanan jenis semu tinggi menempati daerah elevasi tinggi sekitar Gunung Ungaran, dan tahanan jenis semunya semakin menurun dengan semakin besar bentangan $A B / 2-n y a$. Anomali tahanan jenis rendah yang terpetakan di area selatan kemungkinan akibat sedimen Tersier, sampai kedalaman 500 meter.

Penampang tahanan jenis berarah selatanutara (Gambar 6) dan barat-timur (Gambar 7), memperlihatkan penurunan tahanan jenis dengan bertambahnya kedalaman dan mempertegas keberadaan keberadaan anomali rendah di bagian selatan dan timur. Penampang berarah selatan-utara menunjukkan bagian selatan dan timur terdapat lapisan batuan dengan kisaran nilai tahanan jenis 5-20 ohmmeter sampai kedalaman 500 meter, dan diikuti anomali sangat rendah di $<5$ ohmmeter 


\section{MAKALAH ILMIAH}

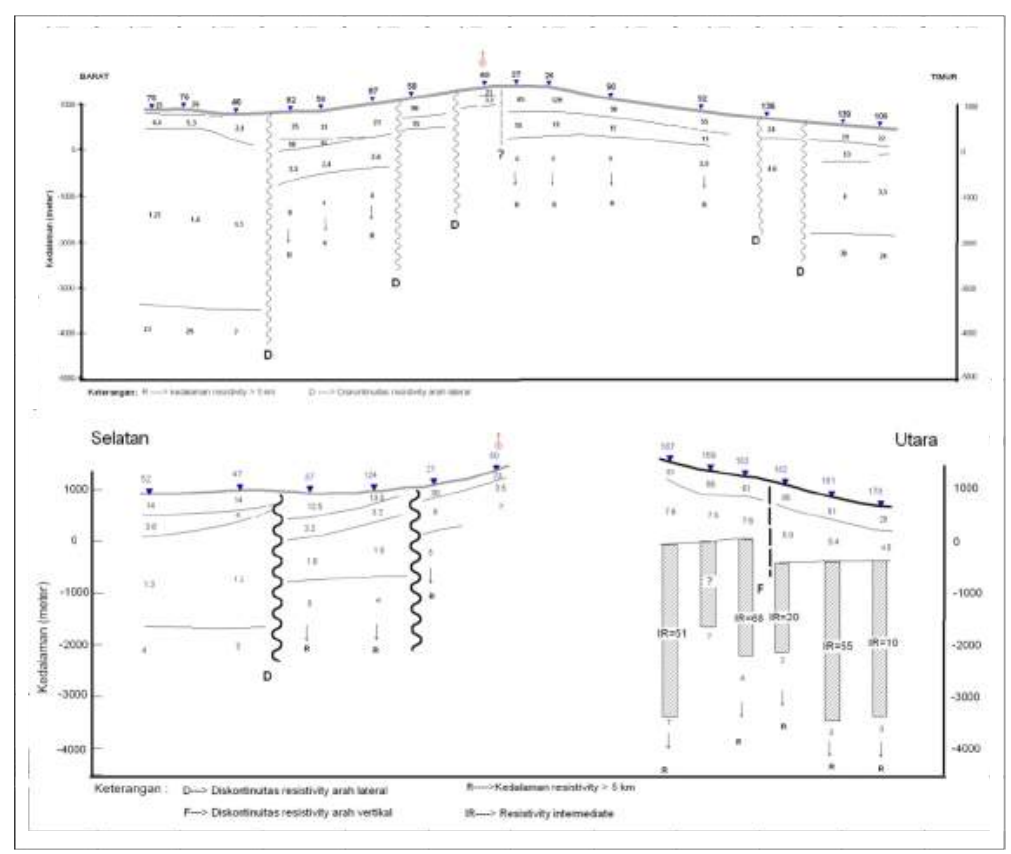

Gambar 9. Penampang tahanan jenis MT (Pertamina, 1984) dimodifikasi dan re interpretasi

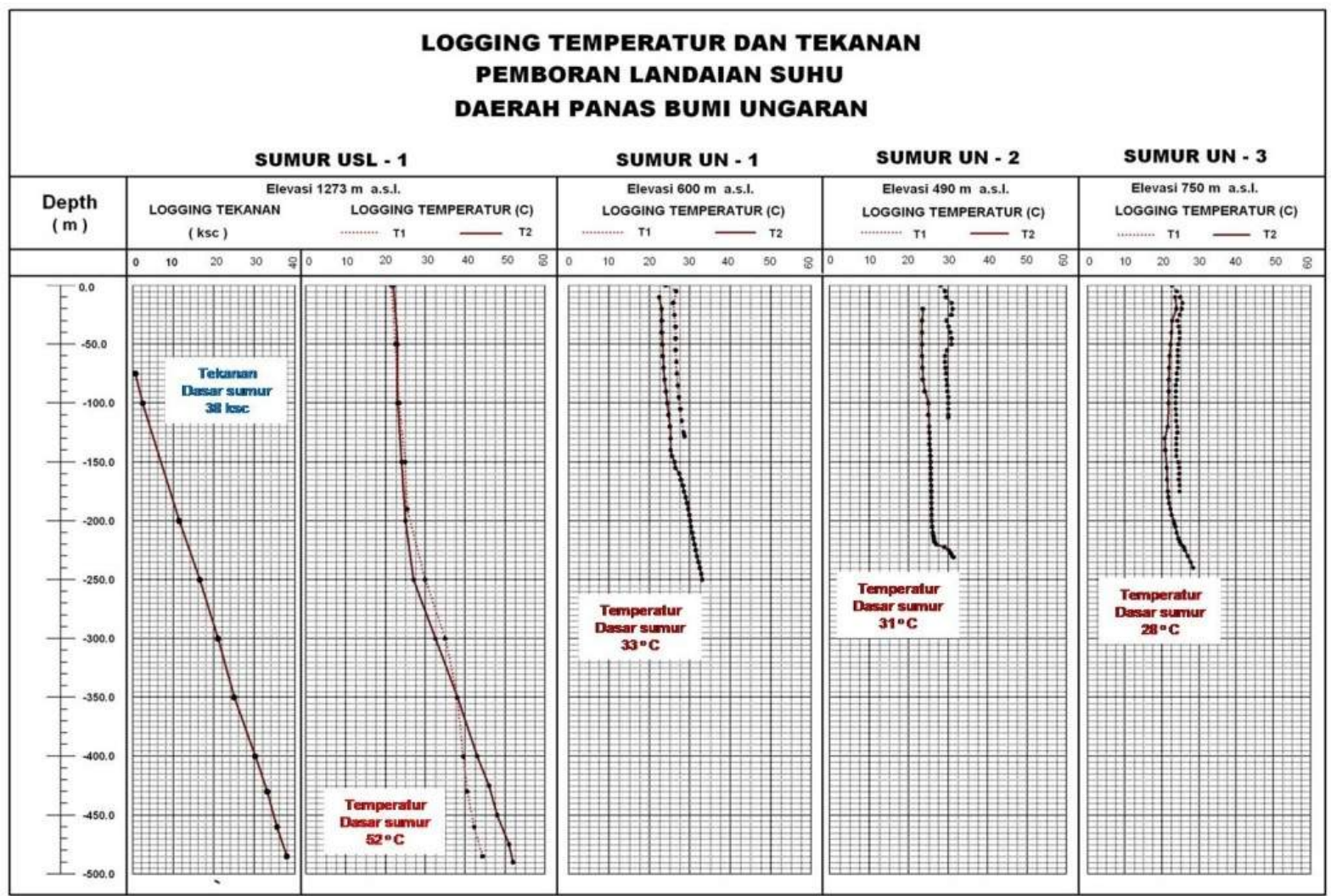

Gambar 10. Logging temperatur dan tekanan sumur USL1, UN1, UN2, UN-3 (Pertamina,1987) 
yang menerus ke bawah. Di sisi utara, nilai tahanan jenis $>20$ ohmmeter berada di kedalaman di bawah 250 meter.

\section{Magnetotelurik (MT)}

Tahanan jenis semu MT menunjukkan tahanan jenis rendah menempati bagian selatan dan tenggara Gunung Ungaran (Gambar 8) dan memiliki kecendrungan penurunan nilai anomali. Anomali rendah di selatan dan tenggara ini diduga berasosiasi dengan sedimen Tersier

Di area manifestasi Ngilmut dan Gedongsongo nilai tahanan jenis relatif tinggi dibanding sekitarnya dan membentuk pola kontur tertutup dengan nilai $>25$ ohmm dan bergradasi meningkat ke arah puncak Gunung Ungaran

Struktur lapisan batuan (Gambar 9) menunjukkan lapisan batuan dengan tahanan jenis $>20$ ohmm yang diduga sebagai batuan piroklastik dengan ketebalan yang bervariasi antara 250-500 meter. Lapisan ini diikuti dibawahnya oleh lapisan batuan konduktif dengan tahanan jenis yang mayoritas bernilai $<10 \mathrm{ohmm}$. Ketebalan lapisan ini belum dapat dipastikan secara pasti karena masih menerus ke kedalaman.

Di daerah sekitar manifestasi Gedongsongo, lapisan konduktif disisipi oleh lapisan batuan dengan tahanan jenis $11 \quad 15 \mathrm{ohm}$ meter yang bergradasi secara vertikal maupun horizontal. Sedangkan di daerah Nglimut terindikasi 2 lapisan batuan, lapisan batuan dengan tahanan jenis relatif tinggi $>30$ ohmmeter yang kemungkinan merupakan batuan produk vulkanik Ungaran yang termuda dengan tebal sekitar 200 meter, kemudian di ikuti lapisan batuan konduktif (<10 ohmmeter) dan lapisan batuan bertahanan jenis intermedian $>20$ Ohmmeter. Sisipan lapisan konduktif ini yang diperkirakan sebagai zona penudung dari sistem panas bumi Ungaran sedangkan lapisan di bawahnya diduga merupakan resevoir.

\section{Pengeboran Landaian Suhu}

Hasil logging temperatur dari keempat lubang sumur landaian suhu memperlihatkan hasil yang berlainan (Gambar 10). Sumur USL-1 mempunyai nilai landaian suhu tertinggi yaitu mencapai $10,4^{\circ} \mathrm{C} / 100 \mathrm{~m}$ atau lebih kurang tiga kali landaian suhu normal dan temperatur di dasar sumur USL-1 tercatat $52^{\circ} \mathrm{C}$ dan tekanan 38 $\mathrm{kg} / \mathrm{cm}^{2}$ (ksc). Sumur ini terletak di sebelah selatan manifestasi fumarol Gedongsongo dengan jarak sekitar $1 \mathrm{~km}$.

Lokasi pemboran UN-1 terletak di kawasan manifestasi Kendalisodo. Korelasi lateral sumur pemboran memperlihatkan bahwa landaian temperatur di sumur UN-1 memiliki trend naik, hal ini memperkuat dugaan bahwa di daerah Kendalisodo terdapat suatu sistem geothermal tersendiri terpisah dengan sistem di Gedongsongo dan Nglimut.

\section{DISKUSI}

\section{Sistem panas bumi}

Berdasarkan hasil analisis data geologi, geokimia, geofisika serta pemboran landaian suhu, sistim panas bumi Ungaran merupakan sistim panas bumi yang terbentuk di komplek vulkanik, dengan batuan penudung berupa batuan vulkanik Gunung Ungaran yang telah terubah dengan ubahan berupa mineralmineral haloisit, kaolinit, silika amorf, kristobalit, ilit, markasit, dan pirit. Berdasarkan interpretasi metoda MT, batuan yang berfungsi sebagai lapisan penudung ini adalah lapisan konduktif (<10 ohmm) dengan ketebalan sekitar 300 - 500 $\mathrm{m}$ di daerah Nglimut dan sekitar $1400 \mathrm{~m}$ di daerah Gedongsongo.

Litologi pembentuk reservoir diduga merupakan batuan vulkanik pra-Ungaran dan sedimen Tersier yang kaya akan rekahan dan bersifat permeabel yang terbentuk akibat aktifitas struktur sesar yang ada atau akibat sifat fisik batuan itu sendiri yang banyak mengandung pori (porous) terutama pada batuan sedimen klastik. Top reservoir berada pada ketinggian sekitar 300 $\mathrm{m}$ di atas permukaan laut, dengan tahanan jenis > 30 ohm-m (berdasarkan MT).

Berdasarkan data geologi regional dan didukung oleh data MT, batuan alas (basement rock) di daerah Ungaran diperkirakan merupakan batuan sedimen laut, batuan ini memiliki sifat permeabilitas serta porositas yang baik. Permeabilitas yang terdapat dalam batuan ini adalah permeabilitas primer berupa ruang antar butir yang saling berhubungan serta permeabilitas sekunder yang terbentuk akibat rekahan-rekahan.

Berdasarkan geologi dan didukung hasil geofisika, sumber panas sistem panas bumi Gedongsongo dan Nglimut diduga sisa panas dari dapur magma Gunung Ungaran Muda berumur Kuarter yang dicirikan oleh adanya anomali Bourguer tinggi di daerah ini. Sedangkan di daerah Kendalisodo sumber panas diperkirakan berasal dari tubuh intrusi yang berasosiasi dengan kubah lava andesitik Gunung Kendalis.

\section{Deliniasi prospek}

Zona prospek panas bumi dideliniasi berdasarkan evaluasi data geosain dan data sumur landaian suhu USL-1. Hasil kompilasi menunjukan tiga kelompok daerah prospek panas bumi di sekitar Ungaran: Gedongsongo 


\section{MAKALAH ILMIAH}

(baratdaya), Nglimut (barat laut) dan Kendalisodo (tenggara). Daerah prospek Gedungsongo dan Ngilmut diperkirakan masih satu sistem panas bumi yang berasosiasi dengan Gunung Ungaran, sedangkan daerah prospek Kendalisodo merupakan sistem terpisah dari kedua sebelumnya.

Deliniasi prospek panas bumi Gedungsongo memiliki luas sekitar $4 \mathrm{~km} 2$ sedangkan daerah Nglimut memiliki luas daerah prospek sekitar $6 \mathrm{~km} 2$ sehingga total luas prospek yang diperoleh dari kompilasi anomali geologi, geokimia dan geofisika adalah $10 \mathrm{~km} 2$ (Gambar 11).

\section{Penghitungan Potensi}

Estimasi potensi dihitung dengan metode volumetri (Tabel 1) dengan asumsi recovery factor $25 \%$, life time 30 tahun, temperatur reservoir $270^{\circ} \mathrm{C}$, temperatur cut off $180^{\circ} \mathrm{C}$ maka potensi panas bumi Ungaran diperkirakan sebesar $110 \mathrm{MWe}$.

\section{KESIMPULAN}

Sistem panas bumi Gunung Ungaran berkaitan erat dengan aktivitas vulkanik Gunung Ungaran. Yang merupakan gunung aktif B yang mempunyai suhu tinggi dengan perkiraan temperatur resevoir $270{ }^{\circ} \mathrm{C}$. Lapisan penudung masih terdeteksi sampai dengan ketinggian 300 dpl yang berarti resevoir sistem panas bumi ungaran berada di bawah kedalam sekitar 1300 $\mathrm{m}$. Luas area prospek panas bumi Gunung Ungaran sekitar $10 \mathrm{~km} 2$ dengan besar potensi $110 \mathrm{MWe}$.

\section{UCAPAN TERIMAKASIH}

Dalam proses penulisan paper ini, kami mengucapkan terima kasih kepada Bapak Safra Dwipa dan Kasbani yang telah banyak memberikan masukan dalam penyelesaian paper serta semua staf Pusat Sumber Daya Geologi khususnya staf-staf di kelompok kerja bidang panas bumi yang turut serta dalam

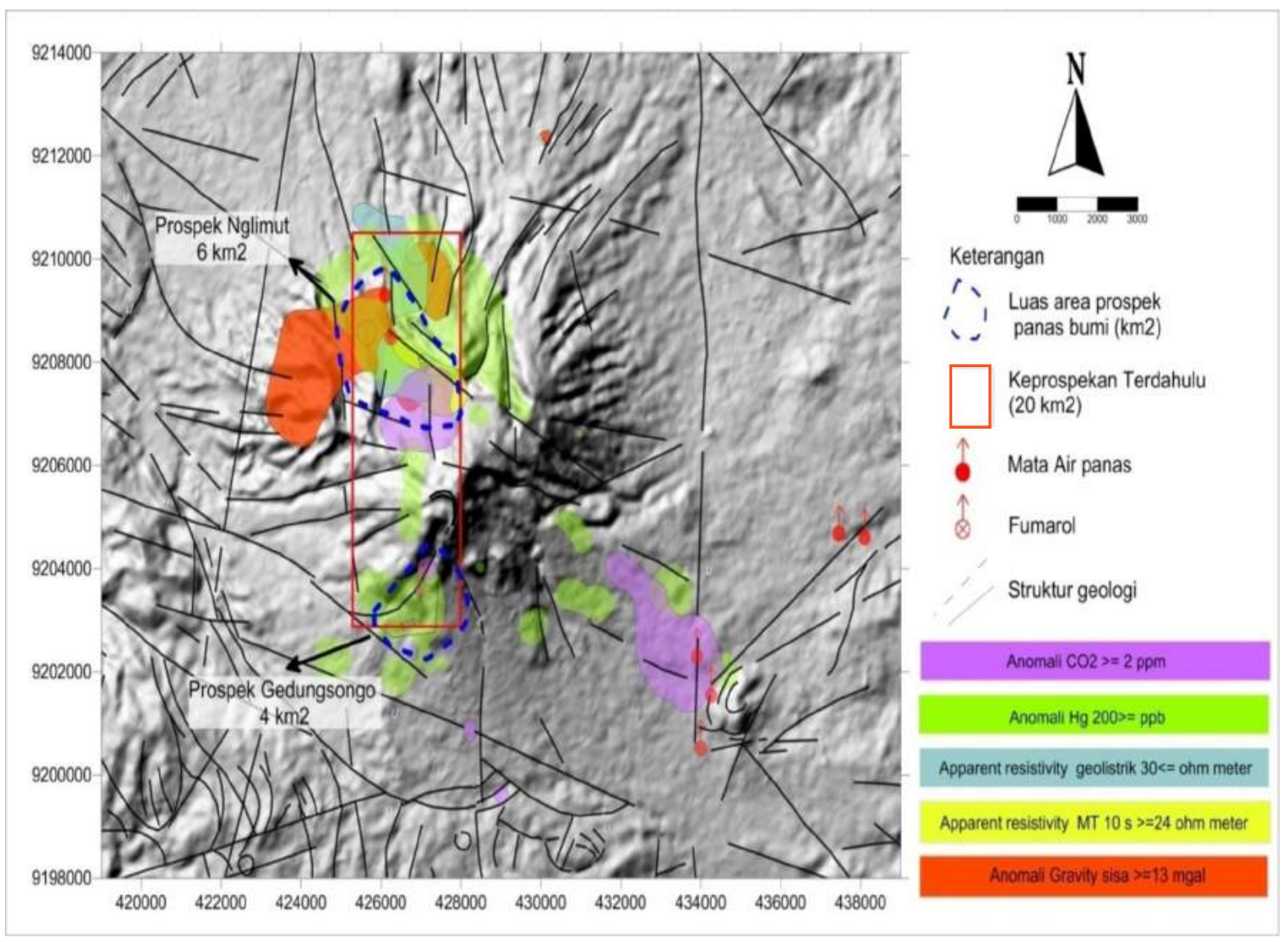

Gambar 11. Deliniasi zona prospek panas bumi berdasarkan geofisika, geologi dan geokimia 
Tabel 1.

Penghitungan metode volumetri potensi panas bumi Ungaran

\begin{tabular}{|r|r|r|r|r|r|}
\hline \multicolumn{2}{|l|}{ PENGHITUNGAN VOLUMETRI (STORED HEAT) } \\
\hline \\
\hline
\end{tabular}

\section{DAFTAR PUSTAKA}

Djoko Sunaryo \& Suranto, 1983, Laporan Pendahuluan geologi daerah Gunung Ungaran, Jawa Tengah. Unpublish report Pertamina, Divisi Geotermal, Jakarta.

Djoko Hantono, Suroto \& Soenaryo. 1987, Evaluasi akhir survey geokimia daerah Ungaran Jawa Tengah. Unpub. report Pertamina, Divisi Geotermal, Jakarta.

Geoco 1984. Magnetotelluric survey for geo- thermal exploration in G. Ungaran Area. Central Java. Unpublished report Pertamina, Divisi Geotermal, Jakarta.

Indarto, Sri. 2006. Studi Batuan Vulkanik dan Batuan Ubahan Pada Lapangan Panas bumi Gedongsongo Komplek Gunung Ungaran, Geotek, LIPI.

Muhardjo, Edy Saputra Rab, Rusdi Yusup, Yuhan \& Hery Sundoto. 1987. Laporan penyelidikan geologi daerah panas bumi G. Ungaran jawa Tengah. Unpub. report, Direktorat Vulkanologi, Bandung.

Nukman, M. 2009. Overview of Gedong-songo Manifestations, Ungaran Geothermal Prospect, Central Java, Indonesia: a preliminary account, Thirty-Fourth Workshop on Geo-thermal Reservoir Engineering Stanford University, Stanford, California.

N. V. Alico 1985. Ungaran resistivity survey, field and interpretation report. Unpub. Report. Pertamina, Divisi Geotermal, Jakarta.

PT. Sumber Daya Bumi. 1991. Survei Hg CO2 di daerah Ungaran, Jawa Tengah. Unpub report Pertamina, Divisi Geotermal, Jakarta.

P.T. Trias Jaya Guna 1986. Penyelidikan gayaberat Gunung Ungaran, Jawa Tengah. Unpubl. report Pertamina, Divisi Geotermal, Jakarta.

P.T. Geoservices (Ltd). 1985. Laporan Pengkajian Foto udara daerah Gunung Ungaran , Jawa Tengah. 
Unpublished report Pertamina, Divisi Geothermal, Jakarta.

P.T. Trias jayaguna 1984. Petrographic description of surface rock samples from Gunung Ungaran, Central Java. Unpublished report Pertamina, Divisi Geotermal, Jakarta.

Thaden, R.E., Sumadirja, H. and Richards P.W. 1975, Peta Geologi lembar Magelang dan Semarang, Jawa.

Van Bemmelen, R.W. 1949. The geology old Indonesia.TheHagu Martinus Nijhoff .

Diterima tanggal 11 Oktober 2011

Revisi tanggal 23 Nopember 2011 